\section{Marginal gaps and internal voids after root-end filling using three calcium silicate-based materials: A Micro-CT analysis}

\author{
Alexander Pompermayer Jardine Q1 ${ }^{1}$, Ketsia Fernanda Váz Rosa ${ }^{2}$, Felipe \\ Barros Matoso [1, Ramiro Martins Quintana ${ }^{1}$, Renata Grazziotin-Soares D 3 , \\ Patricia Maria Poli Kopper Q1,2.
}

\begin{abstract}
This study evaluated the 3D quality of root-end filling, assessing the presence (volume and percentage) of marginal gaps and internal voids formed after retro-filling with three calcium silicate-based materials: MTA Angelus (Angelus Soluçoes Odontologicas, Londrina, PR, Brazil), Biodentine (Septodont Ltd., Saint Maur-des-Faussés, France) and Neo MTA Plus (Avalon Biomed Inc., Bradenton, Florida, US). Thirty human, extracted, single rooted teeth were used. Orthograde root canal treatment, root resection ( $3 \mathrm{~mm}$ shorter than the apex) and retrograde cavity preparation with ultrasonic tips were performed. Teeth were divided into 3 groups $(n=10$ each) following a stratified randomization according to the initial volume of the root-end cavity. After retrofilling, samples were stored for 7 days. Then, two rounds of micro-CT scans were performed: soon after root-end preparation (with the cavity still empty) and 7 days after root-end filling. Marginal gaps, internal voids volume $\left(\mathrm{mm}^{3}\right.$ and \%), as well as, the overall defects (sum of gaps and voids) were evaluated. Statistics compared the three groups in relation to those defects. There was not statistical difference between groups regarding the marginal gaps $(P \geq 0.05)$, the internal voids $(P \geq 0.05)$, and the overall defects $(P \geq 0.05)$. Median $\left(\mathrm{mm}^{3}\right)$ and $\%$ of overall air-entrapment defects (gaps and/or voids) was: $0.004 \mathrm{~mm}^{3}$ and $1.749 \%$ for MTA Angelus, $0.018 \mathrm{~mm}^{3}$ and $6.660 \%$ for Biodentine, and $0.012 \mathrm{~mm}^{3}$ and $4.079 \%$ for Neo MTA Plus. All materials had gaps and/or voids. No differences were found between MTA Angelus, Biodentine and Neo MTA Plus.
\end{abstract}

${ }^{1}$ Graduate Program of School of Dentistry/Endodontics, Federal University of Rio Grande do Sul (UFRGS), Porto Alegre, RS, Brazil.

${ }^{2}$ Department of Conservative Dentistry/Endodontics, School of Dentistry, Federal University of Rio Grande do Sul (UFRGS), Porto Alegre, RS, Brazil.

${ }^{3}$ College of Dentistry, University of Saskatchewan, SK, Canada.

Correspondence: Dr Renata Grazziotin, College of Dentistry, 105 Wiggins Rd, Room E3334, Saskatoon SK, Canada. S7N 5E4. Renata.grazziotin@usask.ca. Phone: (306) 9667813

Key Words: calcium silicatebased materials, microcomputed tomography, root-end cavity, root-end filling.

\title{
Introduction
}

An appropriate root-end filling during apical surgery is important to reach a positive outcome when treating apical periodontitis that affects root-filled teeth ('post-treatment disease' or 'non-healing cases') (1). In these cases, apical periodontitis is caused primarily by residual or subsequent infection after previous treatment (2). Therefore, a root-end filling material, apart from many other ideal features, should be easily placed in the root-end cavity and set without voids/gaps; preventing percolation of fluids, microorganisms and disintegration of the filling (washout) (3).

Since the 90 `s, previous studies that aimed to assess the appropriateness of the retro filling materials have used different techniques (such as, dye penetration and bacterial leakage) to show the sealing ability and marginal adaptation on the interface material-canal wall (4-11). Many materials were used (amalgam, IRM, super-EBA, composites and, calcium silicate-based cements) and primarily assessed by in vitro methods (4-11). These studies were characterized by inconsistency in their results (4-11). Some of the causes for the contradicting results were the different materials tested, the type of dye used, the $\mathrm{pH}$ of the dye and the storage medium for the tooth specimens in dye penetration experiments $(8,12)$; the lack of using microorganisms organized in biofilms, and the relatively long time needed to acquire consistent results in the bacterial leakage studies $(4-8,12-14)$. Other limitation of the past studies was the use of destructive techniques (tooth sectioning, photography, scanning electron microscopy, etc.), which did not allow the use of the same sample for long time evaluations and did not provide a 3D viewing of the material (15).

Currently, micro-computed tomography (micro-CT) analysis may provide clear in vitro results on the quality of root-end fillings, since it is possible to evaluate the volume of the root-end filling material, the gaps between filling material and tooth structure, and the voids inside the material (16). The gaps on the interface material-canal wall might be related to the sealing/adhesive ability of rootend fillings (17), and the voids into the material may demonstrate the efficiency of the filling technique 
and the desired morphologic characteristics of the material (18). One micro-CT study found larger marginal gaps volume for ProRoot MTA ${ }^{\circledR}$ compared to two newly developed cements: Endo CEM MTA $^{\circledR}$ and Retro MTA $^{\circledR}(16)$. The larger marginal gap volumes were related to the material characteristics and/or consistency of ProRoot MTA ${ }^{\circledR}$, which was less sticky than the others, resulting in more difficult handling (16). Recently, researchers suggested that calcium silicate-based sealers could be used in retrograde filling for clinical convenience without harmful effects on the quality of filling (18). They found no difference in air-entrapments defects (marginal gaps and internal voids) between the retrograde fillings performed with a combination of calcium silicate cement plus calcium silicate-based sealer and with calcium silicate cement only, showing that both materials exhibited good adaptation to the retrograde cavity wall (18).

Considering the relevance of having an appropriate root-end filling, this study used three calcium silicate-based materials to investigate the quality of root-end filling: i) MTA Angelus (Angelus Soluçoes Odontologicas, Londrina, PR, Brazil), which is one of the materials that still maintains the original formulation of MTA with bismuth oxide as radiopacifier (19); ii) Biodentine (Septodont Ltd., Saint Maur-des-Faussés, France), a material consisting of a powder component containing silicates, a liquid component contains calcium chloride and zirconium oxide as radiopacifier (20); and iii) Neo MTA Plus (Avalon Biomed Inc., Bradenton, Florida, US) that has similar composition to the original MTA, but it presents tantalum oxide instead of bismuth oxide as radiopacifier (21). Therefore, the aim of this in vitro study was to evaluate the quality of 3D root-end filling, assessing the presence (volume and percentage) of marginal gaps, internal voids and overall defects (gaps + voids) formed after retrofilling with three different calcium silicate-based materials (MTA Angelus, Biodentine and Neo MTA Plus). The null hypothesis of this study was that no difference in presence (volume and percentage) of marginal gaps and internal voids and overall defects would occur in root-end fillings performed with the three materials.

\section{Materials and methods}

The study protocol was approved by the Federal University of Rio Grande do Sul institutional review board (CAAE 87648618.6.0000.5347). The sample size was calculated with OpenEpi software (https://www.openepi.com), using two-by-two comparisons regardless the total number of groups studied (22). To detect a difference of at least 1.0 standard deviation units between the group means, and to reach a $90 \%$ statistical power with $\alpha=5 \%$, the sample size needed was 10 units per group. Thirty human, single rooted mandibular pre-molars, extracted for different reasons were used in this study. Teeth came from patients aged between 18 - 40 years who signed a consent form and donated one tooth each. Teeth were included in the experiment if they had absence of root resorption, root caries, root canal treatment, and canal curvature.

All teeth were disinfected by immersion in $10 \%$ formaldehyde for 6 hours, then cleaned and sterilized in autoclave. Teeth were sectioned at the cement-enamel junction using a cutting machine (ISOMET Low Speed Saw Buehler Lltd., Lake Bluff, IL, EUA) and were stored in saline solution until used.

Pulp and root canal remains were removed with a \#15 K-flex file. Working length was visually determined $1 \mathrm{~mm}$ shorter from the apical foramen. The canals were prepared with \#15 and \#20 K-flex files and Wave One Gold reciprocating file size large \#45.05 (Dentsply Sirona, York, Pennsylvania US). Irrigation was performed with $30 \mathrm{~mL}$ of $2.5 \%$ sodium hypochlorite as the main irrigant, followed by $2 \mathrm{~mL}$ of $17 \%$ EDTA $+2 \mathrm{~mL}$ of saline solution as final flush. Canals were dried with absorbent paper points. Root canals were filled with \#40.05 WaveOne gutta-percha point + AH Plus sealer (Dentsply Sirona, York, Pennsylvania US) and were placed in an incubator under moisture. After 7 days, the roots were resected $3 \mathrm{~mm}$ from the apex at $90^{\circ}$ inclination in relation to the long axis of the root. Resection was performed in the cutting machine under irrigation. Retrograde preparations (3-mm deep, 3-mm wide) were designed with ultrasonic tip (P1M - Surgical, Helse Dental Technology, Santa

Rosa de Viterbo, Brazi). The cavity remained surrounded by parallel dentin walls and a flat floor of filling material (gutta-percha and sealer).

Then, soon after root-end cavity preparation (with the cavity still empty), individual molds of irreversible hydrocolloid polyvinyl siloxane were constructed to hold the roots and the set was scanned by a micro-computed tomography ( $\mu \mathrm{CT}$ ) scanner (SkyScan 1176, SKYSCAN, Kontich, Belgium) operated at $80 \mathrm{KV}$ and $100 \mathrm{~mA}$ with an isotropic resolution of $18 \mu \mathrm{m}$, and field of view of $20.0 \times 9.2$ $\mathrm{mm}$. The whole root was scanned. 
Aiming to obtain the absolute volume values $\left[\right.$ in $\mathrm{mm}^{3}$ ] of the empty cavity, the marginal gaps and the internal voids, the micro-CT images were imported to Image J software (National Institutes of Health, USA). The analysis was performed in the final millimeters of the root apical third, considering the extension of the retrograde preparations $(3 \mathrm{~mm})$. The first selected apical root canal cross-section slice was the one in which the root canal opening was visible. From that point, the slices were run 3 $\mathrm{mm}$ to the cervical direction. The volume of the empty cavity was calculated using the images from the micro-CT scanning by selecting the marginal cavity area in the first and in the final stacks, with the 'freehand tool'. After that, the 'review areas' tool was used to confirm the region that would be analyzed. Then, the empty cavity volume was calculated with the 'set measurements' tool.

Next, teeth were divided into 3 groups ( $\mathrm{n}=10$ each) following a stratified randomization according to the initial volume of the root-end cavity, and the root-end cavities were filled with 1) MTA Angelus, 2) Biodentine or 3) Neo MTA Plus (Table 1). Materials were manipulated according to the manufacturers instructions and root-end filling was performed. Material insertion and vertical condensation was made using n.1 Thimon $+\mathrm{n} .1$ and n.2 Bernabé instruments (Trinks, São Paulo, SP, Brazil). The roots were immediately radiographed to verify the appropriate quality of root-end filling. A single operator performed all procedures wearing 3.5 magnification loupes (Head spot II, MMOptics, São Paulo, SP, Brazil). Samples were maintained at $37^{\circ} \mathrm{C}, 100 \%$ humidity for 7 days.

Table 1 - Calcium silicate-based materials used as root-end filling.

\begin{tabular}{lll}
\hline Material (Manufacturer) & $\begin{array}{l}\text { Batch } \\
\text { number }\end{array}$ & Composition \\
\hline $\begin{array}{l}\text { MTA Angelus (Angelus } \\
\text { Soluçoes Odontologicas, } \\
\text { Londrina, PR, Brazil), }\end{array}$ & 36495 & $\begin{array}{l}\text { Powder: Tricalcium silicate, dicalcium silicate, tricalcium aluminate, } \\
\text { calcium oxide, bismuth oxide } \\
\text { Liquid: Distilled water }\end{array}$ \\
\hline $\begin{array}{l}\text { Biodentine (Septodont Ltd., } \\
\text { Saint Maur-des-Faussés, } \\
\text { France) }\end{array}$ & B10982 & $\begin{array}{l}\text { Powder: Tri-calcium silicate, di-calcium silicate, calcium carbonate } \\
\text { and oxide, iron oxide, zirconium } \\
\text { Liquid: Oxide Calcium chloride and hydrosoluble polymer }\end{array}$ \\
\hline $\begin{array}{l}\text { Neo MTA Plus (Avalon } \\
\text { Biomed Inc., Bradenton, }\end{array}$ & 2014090301 & $\begin{array}{l}\text { Powder: Tricalcium Silicate, Tantalite, Dicalcium Silicate, calcium } \\
\text { sulfate, Silica } \\
\text { FL, USA) }\end{array}$ \\
\hline
\end{tabular}

After this period, the roots were repositioned at the corresponding siloxane mold and scanned again following the same parameters of the first micro-CT acquisition. The images were imported to Image $\mathbf{J}$ and the analysis, for each sample, was performed in the same position of the first acquisition (before retrofilling).

The volume of the internal voids was calculated using the images from the second micro-CT scanning by selecting the borders of the filling material inside the cavity in the first and in the final stacks, with the 'freehand tool'. After that, the 'review areas' tool was used to confirm the region that would be analyzed. Then, the volume of the voids located into the filling material was calculated with the 'set measurements' tool. The volume of marginal gaps was calculated using the images obtained from the second micro-CT scanning by selecting the marginal area of the cavity in the first and in the final stacks, using the "freehand tool". After that, the 'review areas' tool was used to confirm the region that would be analyzed. At last, the volume of overall defects inside the cavity (marginal gaps + internal voids) was calculated using the "set measurements" tool.

Aiming to obtain the volume of marginal gaps, the volume of internal voids was subtracted of the overall defects inside the cavity. The percentages (\%) of marginal gaps, internal voids and overall defects volumes were obtained in relation to the initial volume of the empty root-end cavity.

Absolute values (in $\mathrm{mm}^{3}$ ) and percentages (\%) of marginal gaps, internal voids volumes and Overall defects (gaps + voids), were compared between groups. Kolmogorov-Smirnov test rejected the data normality, and inter-group comparison was made using Kruskal-Wallis test. Statistical analysis was performed using IBM SPSS v.20.0 (SPSS, Chicago, IL, US). Significance was set at 5\%. 


\section{Results}

All groups had marginal gaps and/or internal voids after root-end filling (see an example in Figure 1). Table 2 shows that there was not significant difference between the three groups (MTA Angelus, Biodentine and Neo MTA Plus) in relation to the marginal gaps volume; the internal voids volume; and the overall defects (gaps + voids) $\left(\mathrm{mm}^{3}\right.$ and $\left.\%\right)$.

Table 2 - Median and interquartile range of the volume $\left(\mathrm{mm}^{3}\right)$ and of the percentage $(\%)$ of marginal gaps, internal voids, and overall defects in retro-filled cavities with MTA Angelus, Biodentine and Neo MTA Plus ( $\mathrm{n}=10$ each).

\begin{tabular}{ccccccc}
\hline & \multicolumn{2}{c}{ MTA Angelus } & \multicolumn{2}{c}{ Biodentine } & & \multicolumn{2}{c}{ Neo MTA Plus } \\
\cline { 2 - 7 } & $\mathrm{mm}^{3}$ & $\%$ & $\mathrm{~mm}^{3}$ & $\%$ & $\mathrm{~mm}^{3}$ & $\%$ \\
\hline Marginal Gaps & 0.001 & 0.408 & 0.002 & 0.616 & 0.003 & 0.888 \\
& $(0-0.003)$ & $(0-1.059)$ & $(0-0.019)$ & $(0-9.994)$ & $(0-0.018)$ & $(0.191-7.564)$ \\
Internal voids & 0.003 & 1.532 & 0.006 & 3.642 & 0.004 & 2.253 \\
Overall & $(0.001-0.011)$ & $(0.792-7.399)$ & $(0.001-0.020)$ & $(0.737-6.365)$ & $(0.002-0.015)$ & $(0.556-5.730)$ \\
defects & 0.004 & 1.749 & 0.018 & 6.660 & 0.012 & 4.079 \\
\hline
\end{tabular}

*Kruskal Wallis, $\alpha=5 \%$

\section{Discussion}

This in vitro study used micro-CT analysis to assess the presence (measuring the volume and percentages) of marginal gaps and internal voids formed after root-end filling in extracted human teeth. Findings showed that all the tested calcium silicate-based materials (MTA Angelus, Biodentine and Neo MTA Plus) originated defects after setting. The air-entrapment defects occurred not only in the interface cement-canal wall, but also inside the material (see an example in Figure 1). There was not statistical difference amongst the materials in relation to the amount/percentage of defects formation, confirming the null hypothesis (see Table 2). The three different materials showed a small absolute value of defects (gaps and/or voids), ranging from 0.004 to $0.018 \mathrm{~mm}^{3}$. Although this absolute number seems small, it means that it can reach sometimes $12 \%$ or more of air-entrapment defects on the rootend filling. It is worth highlighting that one of the common bacteria found in the post treatment apical periodontitis, the Enterococcus faecalis (23) is smaller than those air-entrapment defects, having a micrometer-size of approximately $2.0 \mu$ m-diameter (24).
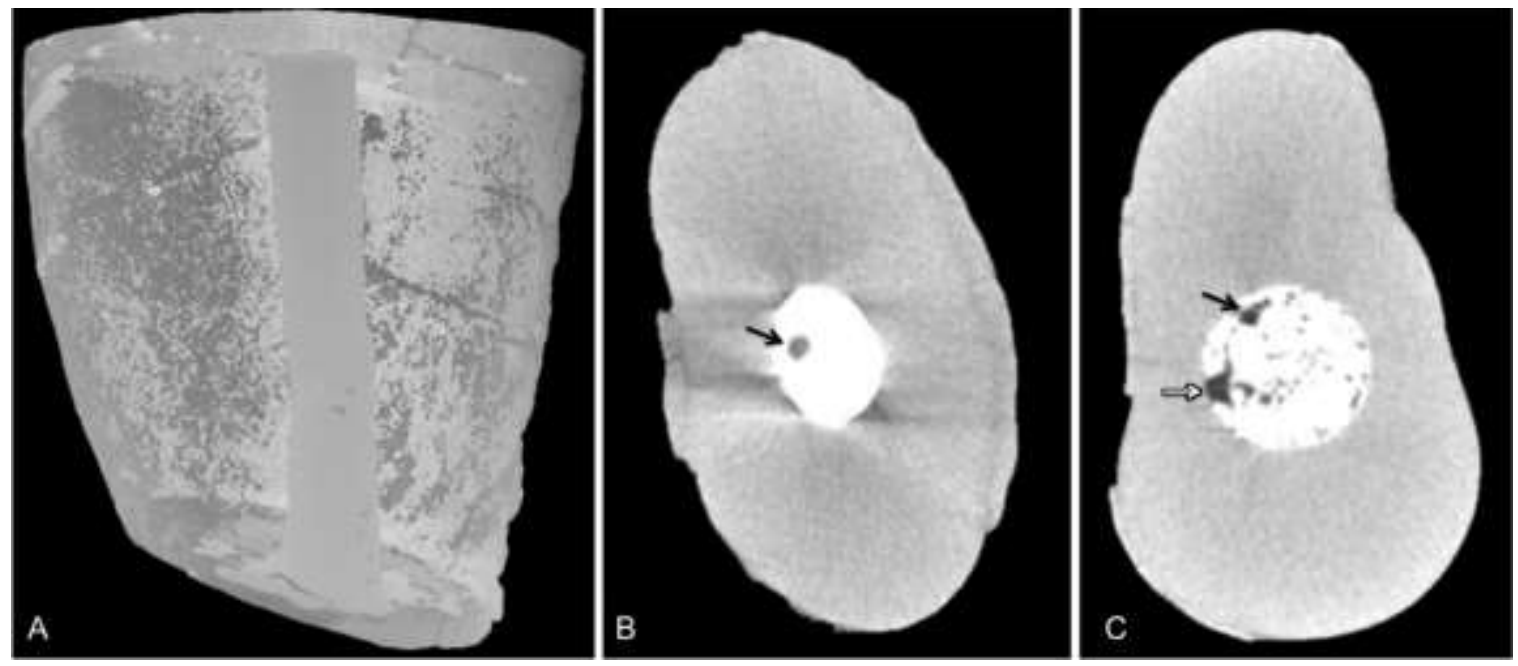

Figure 1 - Representative longitudinal (A) and cross-sectional (B and C) views of root-end fillings (images acquired from Image J). Only the apical third is visible on this image, it is not possible to see the part of the root canal that was orthogradefilled with sealer + gutta-percha. In the cross-sectional view it is possible to see one slice with internal voids ( $\mathrm{B}$, black arrow); and another slice with a combination of internal voids (C, black arrow) and marginal gaps (C, white arrow). 
The statistical analysis found relatively large interquartile ranges (for percentages of defects) for the three groups, even though one single trained operator retro-filled all the samples and careful procedures aiming standardization were performed. This reflects the possibility of some variation in the quality of 3D filling, either having almost no defects or having more than $12 \%$ of overall defects after root-end filling (see these results in Table 2). Certainly, these air defects are not proof that percolation of fluids/microorganism will happen, since material-voids are not the only etiological factor for a good root-end quality (also, the study of micro infiltration was outside the scope of this present work). But, as already stated in the literature, care should be taken during the insertion and compaction of calcium silicate-based materials into the root-end cavity, mainly paying attention to the interface material-canal wall, because a smooth, flat and coherent filling is expected to assure good sealing $(25,26)$. In this regard, this study employed and highlighted the use of ultrasonic tips to improve the mixing and accommodation of the materials into the root-end cavity $(25,26)$.

Regarding the defects that were formed inside the material (internal voids), they could act as microsites to shelter healing tissue and allow periapical revascularization, similarly to a scaffold (27), contributing to a better integration between material and periapical tissues. Therefore, we assume that a small amount of intra-material voids would not be totally disadvantageous. One of our previous studies have already shown that MTA Angelus, Biodentine and Neo MTA Plus (the same materials used in this current study) similarly induced repair and produced good healing features when applied directly onto bone tissue of rats (28).

Albeit the literature have showed that those three materials have different powder/liquid-gel composition, different setting times (Neo MTA Plus > MTA Angelus > Biodentine) and different particles sizes $(28,29)$; in this study, the materials had similar statistical results regarding volume of overall defects formation after root-end filling. One reason for the absence of difference between the materials certainly is the comparability of the experimental groups and the consistent baseline: randomized and morphologically (volume of the cavity) paired. It is important to bear in mind that, although this present study did not used a pre-operative micro-CT to match the whole tooth root canal anatomy (as recommended in the literature) (26) - we did paired the empty root-end cavities; which was the target of our analysis. Another strength of this current methodology is the use of micro-CT as a tool that enables both, 2D and 3D analyses. Therefore, this study is strong in showing a reliable methodology to evaluate marginal gaps and internal voids after root-end filling and to evaluate, both, established and contemporary root-repair materials.

Limitations of this study are the narrow possibility to extrapolate the findings for patients, like any other in vitro experiment (30), and the impossibility to know how much is the 'acceptable' (or appropriate) clinical amount of air-defects into the root-end filling material and/or between the cementcanal wall interfaces (26). Biological research to investigate the interconnection of healing tissue in the innermost of the material-voids is needed.

This in vitro study found material air-defects formation after root-end filling with MTA Angelus, Biodentine and Neo MTA Plus. The three calcium silicate-based materials had no difference in the volume of defects formation either inside the material (internal voids) or in the interface materialcanal wall (marginal gaps).

\section{Acknowledgement}

No funding for this research. Authors deny any conflict of interest.

\section{Resumo}

Este estudo avaliou a qualidade 3D de retro-obturações, avaliando a presença (volume e percentagem) de "gaps" marginais e "voids" internos formados a partir da retro-obturação com três materiais à base de silicato de cálcio: MTA Angelus (Angelus Soluções Odontológicas, Londrina, PR, Brasil), Biodentine (Septodont Ltd., Saint Maur-des-Faussés, França) and Neo MTA Plus (Avalon Biomed Inc., Bradenton, Flórida, US). Trinta dentes humanos unirradiculares extraídos foram usados. Após tratamento de canal ortrógrado, resecção radicular (3 mm apicais), o prepare da cavidade retrógrada com pontas ultrassônicas foi realizado. Os dentes foram divididos em três grupos $(\mathrm{n}=10$ cada) seguindo uma randomização estratificada, de acordo com o volume inicial da cavidade retrógrada. Depois da retro-obturação as amostras foram armazenadas por 7 dias. Duas rodadas de escaneamento de micro-CT foram realizadas: logo após o preparo retrógrado (com a cavidade ainda vazia) e 7 dias após a retro-obturação. O volume de "gaps" marginais e de "voids" internos $\left(\mathrm{mm}^{3}\right.$ e \%), bem como, os defeitos totais (soma de "gaps" e "voids") foram avaliados. Não houve diferença 
estatística entre os grupos em relação aos "gaps" marginais $(P \geq 0,05)$, "voids" internos $(P \geq 0,05)$, e aos defeitos totais $(\mathrm{P} \geq 0,05)$. A mediana $\left(\mathrm{mm}^{3}\right)$ e porcentagem dos defeitos totais de aprisionamento de ar foi $0,004 \mathrm{~mm}^{3}$ e $1,749 \%$ para o MTA Angelus, $0,018 \mathrm{~mm}^{3}$ e $6,660 \%$ para o Biodentine, e $0,012 \mathrm{~mm}^{3}$ e $4,079 \%$ para o Neo MTA Plus. Todos os materiais tiveram defeitos ("gaps"e/ou "voids"). Não houve diferença entre MTA Angelus, Biodentine e Neo MTA Plus.

\section{References}

1. Kruse C, Spin-Neto R, Christiansen R, Wenzel A, Kirkevang LL. Periapical bone healing after apicectomy with and without retrograde root filling with mineral trioxide aggregate: A 6-year follow-up of a randomized controlled trial. J Endod 2016;42(4):533-7.

2. Friedman S. The prognosis and expected outcome of apical surgery. Endod Topics 2005;11:219-62.

3. Torabinejad M, Rastegar AF, Kettering JD, Pitt Ford TR. Bacterial leakage of mineral trioxide aggregate as a root-end filling material. J Endod 1995;21:109-12.

4. Fischer EJ, Arens DE, Miller CH. Bacterial leakage of mineral trioxide aggregate as compared with zinc-free amalgam, intermediate restorative material, and Super EBA as a root-end filling material. J Endod 1998;24:176-9.

5. Adamo HL, Buruiana R, Schertzer L, Boylan RJ. A comparison of MTA, Super-EBA, composite and amalgam as root-end filling materials using a bacterial microleakage model. Int Endod J 1999;32:197-203.

6. Scheerer SQ, Steiman HR, Cohen J. A comparative evaluation of three root-end filling materials: an in vitro leakage study using Prevotella nigrescens. J Endod 2001;27:40-2.

7. Maltezos C, Glickman GN, Ezzo P, He J. Comparison of the sealing of Resilon, Pro Root MTA, and Super-EBA as root-end filling materials: a bacterial leakage study. J Endod 2006;32:3247.

8. Camilleri J, Pitt Ford TR. Evaluation of the effect of tracer $\mathrm{pH}$ on the sealing ability of glass ionomer cement and mineral trioxide aggregate. J Mater Sci Mater Med 2008;19:2941-8.

9. Yildirim T, Er K, Taşdemir T, Tahan E, Buruk K, Serper A. Effect of smear layer and rootend cavity thickness on apical sealing ability of MTA as a root-end filling material: a bacterial leakage study. Oral Surg Oral Med Oral Pathol Oral Radiol Endod. 2010;109:e67-e72.

10. Orosco FA, Bramante CM, Garcia RB, Bernardineli N, de Moraes IG. Sealing ability, marginal adaptation and their correlation using three root-end filling materials as apical plugs. J Appl Oral Sci 2010;18:127-34.

11. Post LK, Lima FG, Xavier CB, Demarco FF, Gerhardt-Oliveira M. Sealing ability of MTA and amalgam in different root-end preparations and resection bevel angles: an in vitro evaluation using marginal dye leakage. Braz Dent J 2010;21:416-9.

12. Pichardo MR, George SW, Bergeron BE, et al. Apical leakage of root-end placed SuperEBA, MTA, and Geristore restorations in human teeth previously stored in $10 \%$ formalin. J Endod 2006;32:956-9.

13. Tobón-Arroyave SI, Restrepo-Perez MM, Arismendi-Echavarrıa JA, et al. Ex vivo microscopic assessment of factors affecting the quality of apical seal created by root-end fillings. Int Endod J 2007;40:590-602.

14. Ferk Luketic S, Malcic A, Jukic S, et al. Coronal microleakage of two root-end filling materials using a polymicrobial marker. J Endod 2008;34:201-3.

15. Zakizadeh P, Marshall SJ, Hoover CI, et al. A novel approach in assessment of coronal leakage of intraorifice barriers: a saliva leakage and micro-computed tomographic evaluation. J Endod 2008;34:871-5.

16. Kim SY, Kim HC, Shin SJ, Kim E. Comparison of Gap Volume after Retrofilling Using 4 Different Filling Materials: Evaluation by Micro-computed Tomography. J Endod 2018;44:635-8.

17. Amoroso-Silva PA, Marciano MA, Guimarães BM, Duarte MA, Sanson AF, Moraes IG. Apical adaptation, sealing ability and push-out bond strength of five root-end filling materials. Braz Oral Res 2014;28:S1806-83242014000100252. Epub 2014 Aug 26. PMID: 25166765.

18. Jung J, Kim S, Kim E, Shin SJ. Volume of Voids in Retrograde Filling: Comparison between Calcium Silicate Cement Alone and Combined with a Calcium Silicate-based Sealer. J Endod 2020;46:97-102. 
19. Parirokh M, Torabinejad M. Mineral trioxide aggregate: a comprehensive literature review — part I: chemical, physical, and antibacterial properties. J Endod 2010;36:16-27.

20. Malkondu O, Karapinar Kazandağ M, Kazazoğlu E. A review on biodentine, a contemporary dentine replacement and repair material. Biomed Res Int 2014:160951.

21. Camilleri J. Staining potential of neo MTA plus, MTA plus, and biodentine used for pulpotomy procedures. J Endod 2015;41:1139- 45

22. Hulley SB et al. Designing clinical research. 3 ed. Philadelphia: Lippincott Williams \& Wilkins, 2007.

23. Siqueira JF Jr, Antunes HS, Pérez AR, et al. The apical root canal system of teeth with posttreatment apical periodontitis: correlating microbiologic, tomographic and histopathologic findings [published online ahead of print, 2020 Jun 7]. J Endod 2020;S0099-2399(20)30383-6

24. Petersen A, Chadfield MS, Christensen JP, Christensen H, Bisgaard M. Characterization of small-colony variants of Enterococcus faecalis isolated from chickens with amyloid arthropathy. J Clin Microbiol 2008;46:2686-91.

25. Machado R, Cruz ATG, de Araujo BMM, Klemz AA, Klug HP, da Silva Neto UX. Tubular dentin sealer penetration after different final irrigation protocols: A confocal laser scanning microscopy study. Microsc Res Tech 2018;81:649 54.

26. De-Deus G, Belladonna FG, Zuolo AS, et al. XP-endo Finisher R instrument optimizes the removal of root filling remnants in oval-shaped canals. Int Endod J 2019;52:899-907

27. Chrepa V, Pitcher B, Henry MA, Diogenes A. Survival of the Apical Papilla and Its Resident Stem Cells in a Case of Advanced Pulpal Necrosis and Apical Periodontitis. J Endod 2017;43(4):561567.

28. Quintana RM, Jardine AP, Grechi TR, et al. Bone tissue reaction, setting time, solubility, and $\mathrm{pH}$ of root repair materials. Clin Oral Investig 2019;23:1359-66.

29. Jardine AP, Montagner F, Quintana RM, Zaccara IM, Kopper PMP. Antimicrobial effect of bioceramic cements on multispecies microcosm biofilm: a confocal laser microscopy study. Clin Oral Investig 2019;23:1367-72.

30. Nagendrababu V, Murray PE, Ordinola-Zapata R, Peters OA, Rôças IN, Siqueira JF Jr, Priya E, Jayaraman J, Pulikkotil SJ, Dummer PMH. A protocol for developing reporting guidelines for laboratory studies in Endodontology. Int Endod J 2019;52(8):1090-1095.

Received: 06/11/2020

Accepted: 24/05/2021 